Article

\title{
Ambidextrous Knowledge and Learning Capability: The Magic Potion for Employee Creativity and Sustainable Innovation Performance
}

\author{
Lucía Muñoz-Pascual *(D) and Jesús Galende $\mathbb{D}$ \\ Department of Business Administration and Management, Multidisciplinary Institute for Enterprise (IME), \\ University of Salamanca, Campus "Miguel de Unamuno", Building FES, 37007 Salamanca, Spain; \\ jgalende@usal.es \\ * Correspondence: luciamp@usal.es; Tel.: +34-923-294-500 (ext. 6825)
}

Received: 6 April 2020; Accepted: 11 May 2020; Published: 12 May 2020

\begin{abstract}
This paper studies the effect that ambidextrous knowledge, i.e., oriented knowledge within a firm towards the development of exploitation activities and oriented knowledge towards the development of exploration activities, has on employee creativity, research and development, and sustainable product innovation. We contend that both tacit and explicit knowledge affect employee creativity, research and development, and sustainable product innovation. We empirically tested our hypotheses by using multisource data collected from 245 Spanish firms across fourteen industries. Our structural equation models indicate that these two types of individual knowledge predict employee creativity, which in turn strengthens research and development projects, and sustainable product innovation performance. The results confirm that the relationships between knowledge, creativity, research and development, and sustainable product innovation performance are strong with a high learning capability. A multi-group structural analysis also reveals that positive relations between tacit and explicit knowledge, employee creativity, research and development, and sustainable product innovation performance are stronger within firms that have employees with high learning capability. We provide pertinent recommendations for managers. The efforts and investments made in knowledge support the development of new ideas, new research and development projects, and sustainable product innovation success; employee learning capability has a strong influence on knowledge, creativity, and sustainable product innovation.
\end{abstract}

Keywords: sustainable product innovation performance; research and development; creativity; ambidextrous knowledge; tacit and explicit knowledge; learning capability

\section{Introduction}

Given the absence of a clear connection between knowledge, creativity and product innovation performance (PIP) [1,2], this paper questions how knowledge could be an antecedent of creativity and sustainable PIP. Advances in the field of knowledge have led to the argument that there is some knowledge that remains tacit, and can only be accessed through informal networks, partners or communications in organizations [3-6]. The suggestion that knowledge processes influence organizational outcomes in informal networks was made some time ago [7]. These lines of thinking stress that there is a variance between an organization's formal denotation (explicit knowledge) and actual (informal) working (tacit knowledge). Explicit knowledge is formal in nature because it comprises formal policies that are "implemented" by management. It is, in our opinion, an incomplete view of the potential impact of knowledge on creativity and PIP, which other components of knowledge can encourage. 
Following the study of Gratton and Ghoshal [8] concerning human capital dimensions as antecedents of innovation (intellectual capital, emotional capital and social capital), this study examines the impact of intellectual capital on creativity, on sustainable innovation performance and on research and development projects.

Indeed, the development and diffusion of sustainable innovations by firms have been deemed necessary conditions for the successful application of new knowledge, thus favoring learning capability while boosting economic growth [9]. Accordingly, sustainable innovations represent a means through which organizations can actually foster new knowledge [10].

The previous arguments emphasize that more research is needed to fully comprehend the interrelated nature of firms' innovation dynamics and knowledge. Furthermore, R\&D and innovation requires a "diverse approach" whereby different knowledge (explicit or tacit) are involved [11-13]. Both types of knowledge, and their interaction, help to clarify the criteria for outcomes and new strategic practices for innovation. In addition, tacit knowledge can become explicit and explicit knowledge can become tacit [14-17].

We propose a research model based on knowledge management as the main driver of research and development $(R \& D)$ and sustainable product innovation in Spanish firms that have obtained three-year funding for the development of R\&D projects.

Innovation is a concept that cannot be understood without knowledge. A process that generates a new project or a new product contains different phases of knowledge-therefore, knowledge and innovation are two concepts that are traditionally connected.

Knowledge and innovation are two key strategic pillars for firms, not only as a source of competitive advantage, but as vital elements for their own survival. They are guidelines for action whose alignment can improve performance. In this sense, this study also considers whether there may be other variables and contingent relations of particular interest to directors and managers that may help explain the relationship between these two elements [18].

In addition, firms now have to differentiate between two main forms of management: One associated with the accumulation and exploitation of resources (generators of stock), and another that is closer to firms that learn, explore, and innovate (generators of flow and capabilities). Those studies on firms that adopt a single form of knowledge management will be short-sighted and unable to exploit their full potential [19-22]. They are opposing, albeit complementary, approaches. Our study is especially relevant because it proposes an integrative model of R\&D and PIP by combining two types of knowledge. Exploration-oriented management will be one that seeks to manage and develop the most tacit part of knowledge, doing so outside the firm's current domain, delving into employees' innermost aspects. On the other hand, exploitation-oriented management will seek to manage and develop explicit knowledge, producing a greater accumulation of stock; that is, physical and economic resources. Therefore, ambidextrous knowledge is oriented knowledge within the firm towards the development of exploitation activities, and at the same time, towards the development of exploration activities.

We empirically tested our hypotheses by using multisource data collected from 245 Spanish firms across fourteen industries. Our structural equation models indicate that these two types of individual knowledge predict employee creativity, which in turn strengthens research and development projects and sustainable product innovation performance.

Thus, this study makes a relevant theoretical contribution, as it proposes an integrative theoretical framework for analyzing employee knowledge, employee creativity, R\&D, and PIP. This paper identifies and analyzes the main theoretical contributions regarding employee knowledge and PIP. We identify the main knowledge and capability (employee learning capability) for the development of creativity, R\&D, and PIP.

Our study's first contribution is, therefore, the integrative theoretical framework for analyzing employee knowledge, R\&D, and PIP.

The second contribution is a detailed comparative analysis of the results obtained from estimating three structural models. On the one hand, we consider the explanatory power of knowledge on 
creativity, R\&D, and PIP. On the other hand, the moderating role of learning capability is added. The results from the different estimations are consistent and reinforce the study's main conclusions. In addition, our structural models are composed of variables on two levels of organizational analysis. At an individual level, we consider knowledge, creativity, and learning capability. These have been measured through the knowledge and objective perceptions that the CEO has about each employee, and the CEO manages their knowledge depending on the information and tools they have access to. At an organizational level, we use R\&D and PIP, measured according to the information the CEO provides about the firm's development of new projects and new products.

The third contribution is to identify the types of knowledge (ambidextrous knowledge) that are sources of employee creativity, R\&D, and PIP. We explore two relevant variables, namely, tacit knowledge and explicit knowledge.

In addition, explicit knowledge and formal education are efficient mechanisms for the development of more productive employees, although this study highlights tacit knowledge as the true generator of new ideas and innovation. New ideas arise from innermost learning and personal experiences. Hence, it is important to study both types of knowledge to test the effects that each one may have on the development of new ideas, $R \& D$, and PIP. We intend to assess whether the incidence of each type of knowledge is needed more during a specific phase of the innovation process, or whether it depends on employees' characteristics and peculiarities. Therefore, we present a new concept: Ambidextrous knowledge-which is based on the orientation of the company's activities towards a more appropriate exploitation of explicit knowledge, and at the same time, towards the appropriate exploration of tacit knowledge.

We consider that a thorough analysis of employee creativity and learning capability are required as internal variables in all innovative processes. We also contribute to the empirical literature on creativity by introducing new metrics in the management field, namely, the Torrance Test of Creative Thinking (TTCT) [23].

In short, the evidence forthcoming in this paper should allow us to deduce the types of knowledge that are needed in the employees' creative process, $R \& D$, and PIP. Furthermore, we consider the moderator role of learning capability. This research contributes to both theoretical and empirical studies on employee creativity, R\&D, and PIP.

The aim here, therefore, is to answer four research questions: (1) Can employees develop new ideas through the management of ambidextrous knowledge? (2) Can firms develop new R\&D projects through the management of ambidextrous knowledge? (3) Can firms improve sustainable product innovation performance through the management of ambidextrous knowledge? (4) Can learning capability influence R\&D and PIP?

The study is structured in the following way: After the introduction, the theoretical framework sustaining the research is explained, and the main hypotheses are presented. The methodology used is then described, including the sample's characteristics, the variables' metrics, and the main results obtained in the structural equation models. Finally, the main results, conclusions, and theoretical and practical implications are presented.

\section{Theory Development}

The resource-based view (RBV) is the main theoretical approach underpinning this research [24], which explains how the influence of valuable resources and capabilities, such as knowledge, positively affects firm performance.

Nevertheless, although this is the main theoretical approach, this study also draws support from other theories. The dynamic capabilities view (DCV) is useful for analyzing the skill (learning capability) that ensures optimal R\&D and PIP. Learning capability is an employee skill, but it can support the development of other firm capabilities and PIP. The DCV is therefore an important theoretical approach in this study. 
In addition, the knowledge-based view (KBV) enables us to explain how knowledge is a firm's most important resource, and can be translated into greater employee creativity and better R\&D and PIP. The Ambidextrous Organizational Approach supports knowledge management according to orientation (exploitation or exploration) for the development of R\&D and PIP within the firm [25].

Finally, Evolutionary Theory explains firms' innovation processes from a dynamic perspective based on different long-term learning patterns [26].

\subsection{Resource-Based View (RBV)}

A resource-based view (RBV) underscores the importance of intangible resources within the organization, such as knowledge, for posting extraordinary results, as a source of competitive advantage. Intangible resources are specific unobservable assets that do not appear on firms' balance sheets or financial statements [27]. These types of resources can help explain differences in innovation. Knowledge is a resource that is susceptible to multiple uses without any loss of value [28].

An RBV not only recognizes the importance of human resources within the organization, but also highlights the fundamental role of technological capacity and innovation. The theory points out accordingly that the firm's technological capacity does not arise from the exploitation of external resources, but fundamentally from the generation and exploitation of internal skills and resources, such as knowledge. This explains the importance of accumulating and managing the heterogeneous resources that help generate new goods and services.

The scarcity and unique and exclusive nature of knowledge enables firms to outperform their competitors. Both knowledge and innovation are based on cumulative processes; that is, they are both generators and stock-flow at the same time.

Prahalad and Hamel [29] consider that the firm's resources and strategic capabilities, such as knowledge, are like the roots of a tree from which new projects and products can grow.

We emphasize the ability to manage and coordinate resources, such as knowledge, to ensure that their integration is reflected in new projects and products. Therefore, the results in terms of innovation are a relevant indicator that the firm can obtain a sustainable competitive advantage.

In short, an RBV is one of the most appropriate perspectives for analyzing knowledge's impact on $R \& D$ and PIP.

\subsection{Knowledge-Based View (KBV)}

This study analyzes employees' knowledge as one of the key resources that organizations can manage for the development of creativity, R\&D, and PIP.

Prior to Spender [30], very few authors had referred to terms related to knowledge within the firm, such as tacit knowledge, competency, or learning capability. However, Spender [30] began to study the implications of knowledge within the firm.

A knowledge-based view (KBV) adopts a perspective on the organization and its competitive advantage based on the study of knowledge. Knowledge is the most important resource within the firm, and it can be created, stored and applied. It is the main source of competitive advantage [31].

Grant and Baden-Fuller [31] are the first to make assumptions:

- Knowledge is a key resource. It is a strategic resource that creates value for the organization.

- Knowledge is composed of information, technology, know-how, and skills.

- Knowledge is acquired by employees, and they are the ones that exclusively store tacit knowledge.

- $\quad$ Employees need to specialize in knowledge acquisition.

- Value creation requires the application of different types of knowledge.

Nonaka [32] argues that it is very important for the organization to implement employee knowledge management practices. Employees may have two types of knowledge: Tacit knowledge (difficult to communicate and formalize) and explicit knowledge (easy to store and transmit). The author argues that the interconnection between them can result in a very valuable type of knowledge for the 
organization. Both types of knowledge and their interaction help to clarify the criteria for outcomes and new strategic practices for innovation. In addition, tacit knowledge can become explicit, and explicit knowledge can become tacit. For example, one learns how to ride a bicycle using explicit knowledge, but uses tacit knowledge while continuing to ride a bicycle for years after. Then, when it comes to teaching someone else how to ride the bicycle, one must switch from using tacit knowledge, to invoking explicit knowledge.

Therefore, a KBV can be understood as an extension of an RBV. Here, the crucial resource is knowledge.

\subsection{Ambidextrous Organisational Approach}

Gibson and Birkinshaw [33] show that managers and employees can direct resources toward exploration and/or exploitation activities. Jarzabkowski et al. [34] argue that firms should create a context for employees' ambition to flourish. Although the ambidextrous literature recognizes the important role employees play in guiding their resources towards exploration and/or exploitation activities, most have focused their studies on the organizational context or climate as generators of ambidextrous behaviors. Therefore, it is important to study the Ambidextrous Organizational Approach on an individual level [35].

Rogan and Mors [36] have highlighted the important role played by human resource management (HRM) within the Ambidextrous Organizational Approach. Employees must be managed to obtain ambidextrous behavior in the firm. Brusoni and Rosenkranz [20] argue that it is essential in changing environments for employees to have a high level of ambidextrous behavior. Ambidextrous HRM should be a priority for managing managers [37]. Managers must be responsible for coordinating HRM towards exploration and/or exploitation activities. Jansen et al. [21] and Alghamdi [22] have reported that ambidextrous HRM helps to generate greater group cohesion and a more proactive attitude towards innovation.

Ambidextrous knowledge is oriented knowledge within the firm towards the development of exploitation activities and towards the development of exploration activities for creativity, research and development (R\&D), and sustainable innovation performance. This employee knowledge, which is essential for the adaptation and survival of the firm, can derive in the search for new opportunities (exploration activities) and in the search for more immediate advantages (exploitation activities). Therefore, the development of ambidextrous knowledge (formal and informal) increases creativity by fostering the ability to explore, support the employee capabilities in a particular area, and boost exploitation skills in that area [38]. Ambidextrous knowledge should, therefore, be a priority for leaders and managers [39,40], as they need to be responsible for marshalling and managing knowledge towards exploration and/or exploitation activities. However, people's ability to behave in an ambidextrous manner is linked to their own characteristics or capabilities, so those individuals that manage to adapt to changes will be those with a more ambidextrous approach.

In short, firms that manage knowledge in an ambidextrous way will be prepared to tackle new challenges, new projects, and sustainable product innovation.

\subsection{Dynamic Capabilities View}

Teece et al. [41] define a dynamic capability as "the capacity of the firms or employees to develop, integrate, build and reconfigure internal and external competencies in environments with a high exchange rate".

On the other hand, Eisenhardt and Martin [42] define a dynamic capability as "a series of routines of employees and the organization by which new configurations can be achieved or the improvement of resources as the firm adapts".

Finally, according to Song et al. [43], a dynamic capability is "the way to manage the resources of the firm for its development, adaptation and integration". Therefore, proper management and 
adaptation of resources to the firm and its dynamic environment can lead to the development of new results in terms of innovation [44].

Consequently, any capacity that renews, develops and adapts competencies and skills to a new scenario or panorama can be called dynamic capacity [41]. Eisenhardt and Martin [42] go one step further, and specify the characteristics that a capacity has to fulfill to be considered as dynamic:

- $\quad$ These are identifiable processes.

- $\quad$ They are developed over time and require continuous processes.

- They depend on the accumulated resources and their adaptation, i.e., they are complex routines.

- $\quad$ They are evolutionary, i.e., they are the result of employee learning.

A DCV is a new extension of an RBV, whereby the skills and competences of both people and firms are relevant for obtaining a competitive advantage. For example, creativity and learning capability.

\subsection{Evolutionary Theory and Innovation}

Evolutionary Theory explains how firms develop their innovative process in a differentiated way, taking into account internal and external aspects [45]. Innovation is composed of endogenous factors and dynamic capabilities. It does not remain stable over time. Innovation results are obtained with different trajectories and patterns of change [26,46,47]. From this perspective, technological development is due to different factors and forces that are in continuous dynamism and evolution.

The firm's cumulative and incremental nature helps explain successful innovation, enabling it to accumulate and store knowledge resources and create new patterns of learning to enhance and obtain new innovation results. The firm depends on its development for successful innovation, as well as for the processes required to learn and provide new solutions [26].

Evolutionary Theory explains multiple determinants of technological change; some external and others internal.

Innovation is the generation, assimilation and exploitation of a new development or technical change. The Oslo Manual [48] considers innovation to be the introduction of a new or significantly improved technical change in products (services).

Other authors, such as Wang and Ahmed [49], argue that innovation is the introduction of technological change or new solutions to problems. However, recent approaches indicate that innovation is a new set of capabilities or management systems that can provide end results with a degree of technical novelty [50].

Here, we study the different sources of knowledge for continuous learning and innovation.

\subsection{Sustainable Product Innovation Performance}

Sustainable product innovation performance is the introduction of a new or significantly improved good or service, in terms of its characteristics or in terms of its intended use. This definition includes the significant improvement of technical characteristics, components and materials, integrated computing, ease of use or other environmental, social and economic characteristics [48].

This study examines the relationship between knowledge (tacit and explicit), R\&D, and PIP. Therefore, employees can develop skills, capabilities, and new flows to increase creativity, and thus, contribute to continuous improvement in R\&D and PIP [51].

\subsection{Research and Development}

This concept can be defined as the creative work carried out systematically to increase the volume of knowledge, including the knowledge of people, culture, and society, and the use of that knowledge to create new applications. There are three activities: (a) basic research, (b) applied research, and (c) experimental development. 
(a) Basic research involves experimental or theoretical tasks undertaken to obtain new knowledge about the fundaments of observable phenomena;

(b) Applied research involves original works carried out to acquire new knowledge. It does, however, serve a specific practical purpose;

(c) Experimental development involves systematic tasks that exploit existing knowledge obtained through research or practical experience, but it is oriented toward the production of new materials or products.

Thus, R\&D is the formal, casual, or occasional research conducted in firms [52].

In this study, we analyzed two types of organizational innovation: sustainable product innovation performance, and research and development. However, the concept of organizational innovation is broader, and other types of innovation can be included. For example, process innovation, radical innovation, or incremental innovation [48].

\subsection{Knowledge}

Knowledge can be defined as the assessment of an individual's learning resources and knowledge that allow them to record a good performance or task, and indicate their sufficiency or suitability for it [53], mainly differentiating between two types:

- Tacit knowledge uses two direct applications of information and knowledge from various sources, such as experience, personal life, etc. This knowledge cannot be stored in books, courses or databases, which is the main reason for its importance to the organization.

- $\quad$ Explicit knowledge allows employees to accumulate information and knowledge through various sources (training courses, databases, university degrees, etc.).

For many years now, the literature has focused on the rational management of resources, such as explicit knowledge, which are a source of stock and important for the development of innovation from an exploitation perspective. Is another perspective called for? Particular emphasis is placed here on ambidextrous knowledge.

Knowledge that is based on a less rational perspective, such as tacit knowledge, is a relevant source of flow that is very important for creativity, R\&D, and PIP [24,27].

In addition, Nonaka and Konno [14] argue that the interconnection between tacit knowledge and explicit knowledge can result in a very valuable type of knowledge for the organization. In the SECI model (Socialization, Externalization, Combination and Internalization), the "model of knowledge production cycles", the following knowledge conversion processes are expressed where both types are interconnected:

Socialization is the process of acquiring tacit knowledge through sharing experiences through oral exhibitions, documents, manuals and traditions, which adds new knowledge to the collective basis of the organization. Externalization is the process of converting tacit knowledge into explicit concepts. This involves making knowledge that is difficult to communicate tangibly through the use of metaphors (concepts, hypotheses, analogies or models), integrating it into the culture of the organization; it is the essential activity in the creation of knowledge. Combination is the process of creating explicit knowledge by gathering explicit knowledge from a number of sources, through the exchange of telephone conversations, meetings, emails, etc. This can be categorized, confronted, and classified into database forms to produce explicit knowledge. Internalization is a process of incorporating explicit knowledge into tacit knowledge, which analyzes the experiences acquired in the implementation of new knowledge. It is then incorporated into the tacit knowledge bases of the members of the organization in the form of models shared mental or work practices.

Therefore, both types of knowledge and their interaction help to clarify the criteria for outcomes and new strategic practices for innovation [14-17]. However, in this study, we focus on determining the impact that each type of knowledge can have on innovation and R\&D. The objective is to determine whether a type of knowledge can positively influence innovation and R\&D. 
The effects that knowledge can have on innovation are not independent of the context, employee capabilities, or level of creativity. In addition, contextual variables have different levels of analysis (individual, group, and organizational) [54]. All are necessary for innovation [38-40]. Creativity and learning capability are considered here as factors that improve the relationship between knowledge, $R \& D$, and PIP.

\subsection{Creativity and Learning Capability: The Keys to Successful Innovation}

This study examines the creativity and learning capability; both are considered factors that intervene between knowledge, R\&D, and PIP.

Creativity can be defined as the production of new ideas that will help firms develop new products or processes [55]. Individual creativity is analyzed here [23].

Creativity is an intervention mechanism between knowledge, R\&D, and PIP, and it is an important channel [41]. Work teams in firms may be able to generate environments and routines in which creativity is developed, whereby it may be considered a dynamic capability developed to obtain R\&D and PIP $[51,56]$.

Zollo and Winter [57] argue that skills will help to generate mechanisms or ideas for greater effectiveness in firms. Accordingly, and before improving their PIP, firms will have highly creative individuals with learning patterns and capabilities. Consequently, and depending on complexity, competitive environment, or dynamism, employees may generate more or fewer ideas.

If creativity is an aspect to be taught and developed within the firm, those firms that suitably manage motivation may develop creativity. Following the RBV, firms with a good PIP performance will have the employees and creative practices required to achieve it. Additionally, if a competitive advantage is based on the accumulation of resources and strategic capabilities, creativity may be considered a source of competitive advantage [24].

Learning capability can further develop the generation of new ideas, fostering the creation of new projects or innovations. If an employee has a high learning capacity, they will be alert, capturing knowledge and integrating it into new ideas or new innovation processes [58-60].

Several arguments justify the use of learning capability as a moderating variable between knowledge, creativity, R\&D, and PIP. First, employees not only accumulate knowledge within the organization (stock), but they also possess, develop, and hone skills, such as their learning capability (flows), which help strengthen knowledge for the development of a new idea, a new project, or a new product. Second, we can justify the existence of learning capability as a moderating variable if we consider it a complementary asset. Those employees that achieve a certain degree of learning capability will help the organization obtain a competitive advantage. From this perspective, firms also need employees that have developed their learning capability [61]. The relationships between knowledge and creativity are antecedents to R\&D and PIP. Learning capability is a moderator variable between these relationships (Figure 1). 


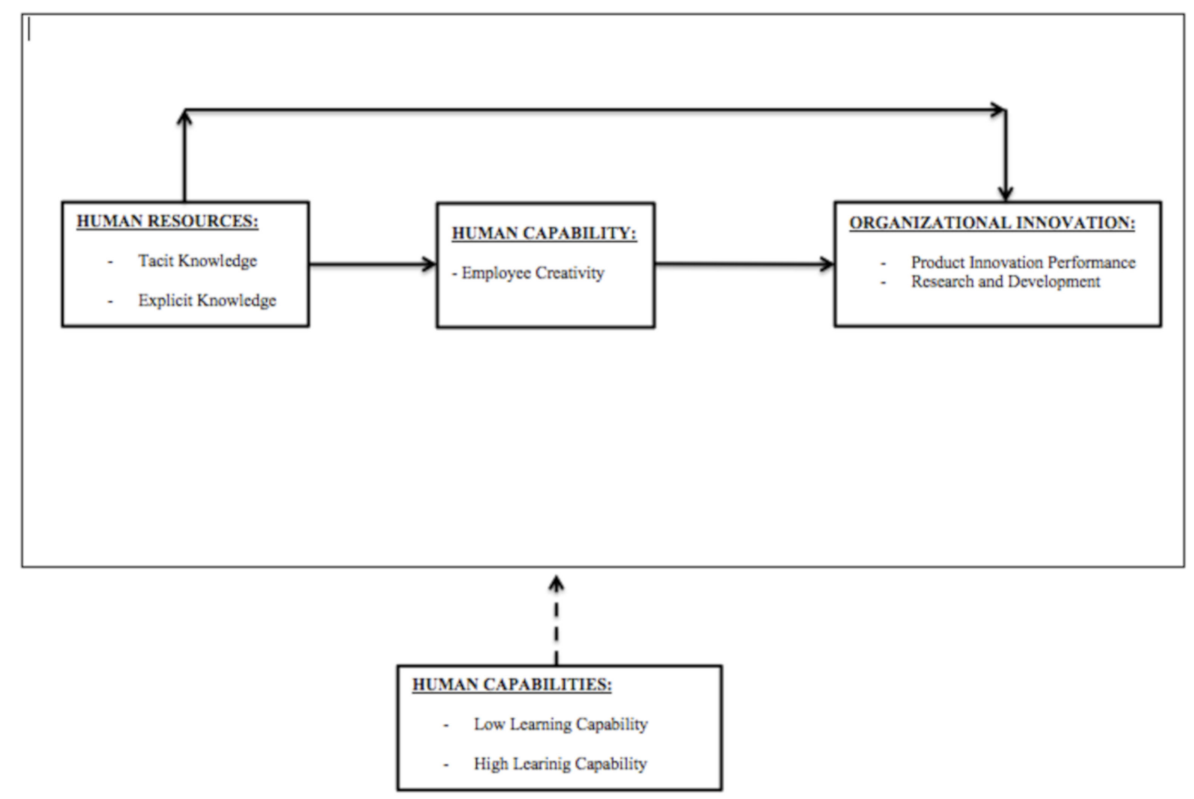

Figure 1. The theoretical framework of sustainable product innovation performance and research and development.

\section{Hypotheses Development}

This study considers the two types of knowledge employees may have identified and analyzed in the previous literature. This will allow analyzing the relative impact each type of knowledge has on each phase of the innovation process [2,62].

Knowledge arises when individuals interpret and use information related to their own experiences, whereby it arises not only from documents or databases, but also from processes and practices. There are several types of knowledge: tacit and explicit, individual and collective, external and internal, and know-how and know-why [63-65].

This research focuses on knowledge that is based on the classification established by Leiponen [63], which distinguishes between tacit knowledge and explicit knowledge.

Some authors refer to codified knowledge within the firm as one that is contained in technology, databases, or is obtained through training courses. Other authors indicate that knowledge is found in relationships, communication, experiences, shared information, the exchange of documents, consultations, etc. [66-70]. We understand that knowledge can be classified according to two types: (1) As those practices that seek to promote employees' uncoded and informal knowledge; that is, tacit knowledge; (2) as those practices or training actions that seek to accumulate and manage technical or coded knowledge; that is, explicit knowledge.

We present the hypotheses as the effects each type of knowledge can have on creativity, R\&D, and PIP. The study of both types of knowledge is relevant when identifying how and when each of them intervenes both in the process of generating new ideas and launching new products [63-71].

Creativity may be easier for employees because employee knowledge accumulates at different rates. Whereas, tacit knowledge generates more efficient production processes, greater self-learning, and consequently, helps to improve the creative process. It may, therefore, be affirmed that tacit knowledge helps to generate new ideas. Leiponen [63] argues that tacit knowledge is more likely to generate new ideas. Therefore:

Hypothesis 1 (H1). Tacit knowledge has a positive impact on employee creativity.

We argue that knowledge should not be regarded from an explicit perspective alone, as we are also interested in the potential impact of a tacit perspective on creativity. Along these lines, we contend 
that creativity is easier to achieve in some firms than in others. This is due largely to the fact that each firm's knowledge advances at a different pace depending on its employees. Improvements in tacit knowledge generate more efficient production processes, greater self-knowledge and enhanced learning for the creative process. Thus, it may be contended that the greater the tacit knowledge, the bigger the incentive for employees to generate new ideas, since there is a greater likelihood of obtaining positive results [71].

On the other hand, knowledge from courses or training practices may generate new learning capabilities, and therefore increase the generation of new ideas. Employees need technical skills to create new ideas and solutions in their fields of work. Explicit knowledge is easily transferable and marketable [63]. Therefore:

Hypothesis 2 (H2). Explicit knowledge has a positive impact on employee creativity.

Hayton [72] and Paton [73] find a positive relationship between certain factors of knowledge and the generation of new ideas. For example, diversity can prompt employees to seek new knowledge and new cognitive approaches that promote creativity. Taggar [74] indicates that employees with knowledge extracted quickly and effectively have a positive influence on the generation of new ideas. Dyer and Shafer [75] report that employees with a high level of tacit knowledge generate creative and innovative ideas.

In addition, Van de Ven [76] indicates that studying innovation requires knowing the factors that facilitate the process. This author argues that the ideas developed by employees are a relevant factor for an innovation process. Amabile et al. [77] indicate that employees' creative solutions have a major presence in innovation. The impact of employee creativity on R\&D and PIP is now analyzed:

Hypothesis 3a (H3a). Employee creativity has a positive impact on PIP.

Hypothesis $3 \mathbf{b} \mathbf{( H 3 b ) . ~ E m p l o y e e ~ c r e a t i v i t y ~ h a s ~ a ~ p o s i t i v e ~ i m p a c t ~ o n ~ R E D . ~}$

Sustainable product innovation performance is the result of successfully exploiting new knowledge [78]. This process comprises technical design, R\&D, manufacturing, management, and the commercial activities that comprise the marketing of a new (or improved) product. There are certain antecedents of innovation (knowledge, creativity, and LC) that stimulate the development of PIP [79-81]. Only one antecedent is not sufficient or necessary for PIP [82,83].

These relationships have not been analyzed in depth by the previous literature $[18,84]$. Our study addresses the important role that individual creativity plays between R\&D and PIP.

We analyze not only the direct effects but also the indirect effects, which can help us fully understand the study of the complex relationships between knowledge and innovation [85].

First, some authors argue that knowledge is a resource that employees have within their intellectual grasp [8,86]. Edvinsson and Sullivan [87] argue that innovations create value within the firm, and that many of these innovations stem from employee knowledge. Therefore, firms that efficiently manage employees' knowledge are able to establish processes for evaluating and testing innovations [88].

Authors, such as Tödtling et al. [89], indicate that it is still not clear to what extent innovation is based only on technical or specific knowledge (explicit knowledge). The author argues that studies are needed to divide the construct into two (tacit knowledge and explicit knowledge). Configurational recipes for managers could, thus, be obtained, and thereby identify, direct, and develop two types of knowledge according to the firm's interests [90].

Hayton [72], Leiponen [63], and González-Álvarez and Nieto [66] consider it relevant to distinguish between both types of knowledge when studying product innovation. Hayton [72] shows that both types of knowledge are relevant. Leiponen [63] reports that explicit knowledge influences product innovation, but tacit knowledge does not. Hegde and Shapira [91] indicate that training courses have a positive influence on product innovation. Pizarro et al. [92] argue that explicit knowledge can be 
translated more easily into product innovation. Taggar [74] and Papa et al. [93] contend that employees with a high level of information and explicit knowledge will be able to capture this knowledge in new products more effectively.

However, authors, such as Díaz et al. [94], and Dyer and Shafer [75], find that tacit knowledge has a positive influence on product innovation. The tacit knowledge resulting from the experience may contribute considerable value during the entire innovation process. The experience is difficult to transmit, and employees owning it can better face the new challenges that every innovative process involves. Innovation requires employees with unique and exclusive knowledge [95].

Our study also considers it important to introduce a new relationship between both types of knowledge and $\mathrm{R} \& \mathrm{D}$, so $\mathrm{H} 4 \mathrm{~b}$ and $\mathrm{H} 5 \mathrm{~b}$ are considered, as tacit knowledge may be relevant in the initial phases of R\&D.

Leiponen [63] has revealed that the investment and management of tacit knowledge can be controversial because it is a very specific resource controlled by employees. A direct relationship also needs to be established between explicit knowledge and R\&D. Therefore:

Hypothesis 4a (H4a). Tacit knowledge has a positive impact on PIP.

Hypothesis $\mathbf{4 b} \mathbf{( H 4 b )}$. Tacit knowledge has a positive impact on RED.

Hypothesis 5a (H5a). Explicit knowledge has a positive impact on PIP.

Hypothesis $5 \mathbf{b}(\mathbf{H} 5 \mathbf{b})$. Explicit knowledge has a positive impact on RED.

Following Kianto et al. [96], knowledge is the most important resource for PIP in firms. Xie et al. [97] reported the positive effect of knowledge on PIP. Knowledge appears to be an effective approach to obtaining new mechanisms and information to develop PIP and R\&D [98].

Finally, this study goes a step further by proposing a contingent relationship in the effects that learning capability can have on the research model $[58,99]$.

Van de Ven [76] has argued that context, culture, and human capabilities are factors that facilitate the innovation process. Salman and Saives [100] indicate that human capabilities make innovation results stronger. Aiman-Smith et al. [101], and Hegde and Shapira [91] indicate that firms supporting the learning capability will achieve innovation success more easily. Learning capability may have a positive influence on innovation. Finally, Subramaniam and Youndt [102] argue that learning capability helps strengthen knowledge, R\&D, and PIP.

Our model suggests that employees with high learning capability facilitate innovation results. Therefore:

Hypothesis 6 (H6). Learning capability moderates the relationships between tacit/explicit knowledge, creativity, sustainable product innovation performance, and research and development, whereby relationships are stronger in firms with a higher level of learning capability.

\section{Methods}

\subsection{Sample and Data Collection}

The hypotheses were tested through Structural Equation Modeling (SEM). A sample was drawn from innovative Spanish firms across fourteen different industries listed in the database of the "Centro para el Desarrollo Tecnológico Industrial" (CDTI) and "Sistemas de Análisis de Balances Ibéricos" (SABI) for 2017, 2018, and 2019.

These innovative firms were selected because they have received funding for R\&D projects from the Spanish government. The information was collected through an ad-hoc online survey. The initial population consisted of 1446 firms across fourteen different industries. 
This study collects data from two very heterogeneous secondary information sources (CDTI and SABI) and a primary information source (survey). The final sample of 245 firms participated in the data gathering, and provided sufficient information for the analysis. These data represent a $16.94 \%$ response rate, with a sampling error of $+/-5.71 \%$ at a confidence level of $95 \%$.

The surveys were managed online using the SurveyMonkey payment platform. To identify any possible errors of interpretation in the language used, the survey was initially drafted in English. The back-translation method was used for the survey items.

The questionnaire was originally written in English, and then translated into Spanish by a certified translator, and then back-translated into English. Before the survey's design, a pre-test was carried out with five prestigious scholars and managers that helped draft the final version. Finally, the firms were contacted by telephone to introduce the study, and mass mailings of the survey were then made to them. The survey took $20 \mathrm{~min}$, with the respondents being the CEOs within each firm. CEOs are responsible for making decisions, and they have all the information and tools regarding employee knowledge and organizational R\&D and PIP. This means the CEOs will have a realistic view of the knowledge since knowledge management is a strategic issue for R\&D and PIP. Our goal is not to measure knowledge, creativity and learning capability through employees. This study intends to go one step further to measure its impact on organizational R\&D and PIP, whereby the CEO needs to be consulted on employees' knowledge, creativity, and learning capability, and organizational R\&D and PIP from a management perspective [103].

Our final sample of 245 firms is composed of fourteen industry categories: agriculture and livestock $(\mathrm{N}=4)$, manufacturing $(\mathrm{N}=110)$, power and gas supply $(\mathrm{N}=3)$, water supply and pollution $(\mathrm{N}=3)$, building $(\mathrm{N}=10)$, vehicle trade and repair $(\mathrm{N}=27)$, transport and storage $(\mathrm{N}=2)$, catering $(\mathrm{N}=2)$, information and communication $(\mathrm{N}=27)$, housing $(\mathrm{N}=1)$, scientific activities $(\mathrm{N}=47)$, administrative activities $(\mathrm{N}=5)$, health activities $(\mathrm{N}=3)$, and other services $(\mathrm{N}=1)$.

An ANOVA test of differences of means was conducted to check for the presence of Common Method Bias, with relevant aspects that could affect the sample's behavior being compared subsequent to the statistical analyses, such as size (headcount) and seniority (age), among fifty late respondents ( $\mathrm{N}=50$ late respondents) and fifty early respondents ( $\mathrm{N}=50$ first respondents) [104].

The ANOVA did not reveal any significant differences between early and late responses. We can therefore reject the null hypotheses with no differences between the mean headcount $(1.672, p=0.199)$ and seniority (age) $(0.041, p=0.840)$. It may be concluded that there is no Common Method Bias, and the sample suitably represents the population.

\subsection{Measures}

All the variables were rated on a seven-point Likert-type scale, ranging from 1 (strongly disagree) to 7 (strongly agree).

\subsubsection{Knowledge (KNOW)}

The dimensions and items of knowledge (KNOW) were measured by a Likert scale with nine items grouped into two dimensions: Four items for Tacit Knowledge (TA_KNOW) [71,105,106], and five for Explicit Knowledge (EXP_KNOW) [107,108], considering the knowledge that encourages employees to work towards their goals according to the CEO's information and tools.

Tacit knowledge (TA_KNOW) is all items specifically based on tacit knowledge, and explicit knowledge (EXP_KNOW) is all items specifically based on explicit knowledge. Items that may be the result of a combination of tacit and explicit knowledge are not considered here.

\subsubsection{Creativity (CREA)}

Employee Creativity (CREA) is a one-dimensional variable. A Likert scale with seven items was used to measure CREA: Four items adapted from Torrance Tests of Creative Thinking (TTCT) [23], and three items of our own according to the CEO's perceptions, knowledge, and management tools. 
The TTCT is perhaps the most widely used instrument for identifying creative abilities within the international context of education and psychology. TTCT evaluates creative thinking at an individual level through different tests of verbal and figurative production that the CEO obtains from their employees. These tests are evaluated according to fluency, originality, elaboration, and flexibility, thus contributing a new practical application of TTCT in the field of management.

\subsubsection{Sustainable Product Innovation Performance (PIP)}

PIP is a one-dimensional variable. A Likert scale with three items was used: number of product innovations, new product sales, and new products compared to portfolio products $[49,109]$.

\subsubsection{Research and Development (R\&D)}

R\&D is a one-dimensional variable. A Likert scale with three items was used: number of employees dedicated to R\&D, R\&D expenditure, and hours dedicated to R\&D [110,111].

\subsubsection{Learning Capability (LC)}

Learning Capability (LC) is a multi-dimensional variable [112-114]. A Likert scale with four dimensions and fourteen items was used: earning commitment (LC1), system perspective (LC2), opening and experimentation (CA3), and knowledge transfer (LC4).

\subsubsection{Control Variables}

Finally, two control variables are considered: size and age [115].

Size

Some previous studies suggest that the size of the firm is linked to innovation [116], although the meaning of the relationship is still not very clear. On the one hand, a series of factors seem to indicate that a larger firm size can positively affect innovation results, since there is a greater possibility of obtaining economies of scale in R\&D, less risk, and the possibility of making profits from Innovative results more easily. Ultimately, larger firms can access a broader range of human capital knowledge and skills than smaller firms, allowing for higher rates of creativity and innovation $[117,118]$.

On the other hand, another series of factors indicate that a smaller size of the firm can positively affect the results of innovation, since there may be a better communication network, coordination and greater motivation and predisposition to improvement and creativity on the part of workers. In addition, with a smaller firm size, there is a greater presence of controls and strategic and informal incentives that help to innovate in the long term and a greater ability to specialize in niche markets $[117,118]$.

Therefore, there are arguments in favor of both extremes. Rothwell and Dodgson [118] pointed out that large entities have material advantages (financial resources, exploitation of synergies, superior scientific personnel, etc.), while those of small entities are associated with behavioral factors (fluid communication, organic structure, informal management, etc.). That is why small firms can be more effective in the initial stages of the product life cycle, when differentiation is more relevant; and larger entities can be more effective in the maturity stage, as the material advantages becomes more important cost.

The size of the firm can be measured through various indicators, such as the entity's added value or the number of employees. In this sense, the previous literature is not conclusive. Adams [119] verifies that size, measured through the number of employees, is not a relevant factor in the intensity of R\&D on sales. Graves and Langowitz [117] find, for the pharmaceutical industry, that large firms with a larger number of employees are less efficient in generating innovations, an issue that they attribute to factors, such as their more bureaucratic and conservative nature. In contrast, Worley [120] finds a significant relationship between the number of employees and the intensity of R\&D on sales in industries in the oil and electrical machinery sector. At an intermediate point, some studies show that both extremes of size 
are the most innovative. In this sense, the works of Rothwell [121], Pavitt et al. [122], and Rothwell and Dodgson [118] find that the relationship between developed innovations and size follows a U-shape, with small and large innovations.

The present study measures the size of the firm by the number of employees.

Age

The age of the firm, as a reflection of the experience and knowledge accumulated throughout its history, can also affect to better communication management and the creativity necessary to innovate, as well as an effective learning capability [123].

Specifically, Busom [124] finds a positive relationship between the age of the entity and the probability of carrying out basic and applied research, as well as with the amount invested in these activities. Kumar and Saqib [125] also find a positive relationship between the experience of the firm, measured through age, and the performance of $R \& D$, although the level of significance is low and the relationship is not manifested on the intensity R\&D. Kuemmerle [126] analyzes the relationship between the innovative result of $R \& D$ laboratories, measured through interviews with their managers and by obtaining patents and their experience, finding a positive relationship, which can be extended to the possibility to make a better design and management of new laboratories that are created. Gumbau [127] verifies that the time the firm has been operating in the market positively influences the level of resources invested in R\&D in the case of medium-sized firms.

On the contrary, the works of Molero and Buesa [128] show that newly created firms are the most active in dedicating resources to innovation. Huergo and Jaumeandreu [123] indicate that the probability of innovating decreases with the age of firms, so that young firms are more likely to innovate, while older firms are less innovative.

This study measures the age of the firm by the number of years from its creation to the present.

Therefore, firm size and age are critical firm-specific factors that affect PIP [129].

Table 1 provides a summary of the model's main scales: items, loading factors, variance explained, and Cronbach's alpha.

Table 1. Items and loading factors.

\begin{tabular}{lc}
\hline & Loading Factor \\
\hline Knowledge $(K N O W)$ (V.E $=54.35 \%)$ & \\
1 Factor: Tacit Knowledge (TA_KNOW) $[71,105,106](\alpha=0.79)$ & 0.80 \\
TA1_KNOW. Technical skills of employees to do their job & 0.78 \\
TA2_KNOW. Implementation of practical and applied training courses & 0.78 \\
TA3_KNOW. Experience of employees in relation to their work & 0.74 \\
TA4_KNOW. Implementation of interdisciplinary training & 0.63 \\
TA5_KNOW. Total sales training expense & 0.44 \\
TA6_KNOW. Employees who receive training & \\
2 Factor: Explicit Knowledge (EXP_KNOW) [107,108] $(\alpha=0.76)$ & 0.84 \\
EXP7_KNOW. Electronic resources (Information collected in databases, files, intranet) & 0.76 \\
EXP8_KNOW. Higher qualification (graduate, engineer, master, doctorate) & 0.51 \\
EXP9_KNOW. Information on raw materials and finished products & \\
\hline Creativity (CREA) [9] (V.E = 75.09\%); $(\alpha=0.94)$ & 0.90 \\
CREA1. Curiosity and pro-activity & 0.92 \\
CREA2. Idea production & 0.88 \\
CREA3. Production of diverse solutions & 0.88 \\
CREA4. Production of infrequent solutions & 0.79 \\
CREA5. Care, detail and elaboration with which they carry out their work & 0.85 \\
CREA6. Spontaneity and improvisation & 0.84 \\
CREA7. Energy and vitality & \\
\hline
\end{tabular}


Table 1. Cont.

\begin{tabular}{lc}
\hline & Loading Factor \\
\hline Sustainable Product Innovation Performance (PIP) [49,109] (V.E = 73.69\%); $(\alpha=0.68)$ & \\
PIP1. Number of innovation in product & 0.82 \\
PIP2. Sales of new product & 0.78 \\
PIP3. New Products comparison with portfolio products & 0.75 \\
\hline Research and Development (R\&D) [110,111] (V.E = 90.85\%); $(\alpha=0.95)$ & \\
R\&D1. Employees dedicated to R\&D & 0.96 \\
R\&D2. R\&D expenditure/Sales & 0.95 \\
R\&D3. Hours dedicated to R\&D & 0.95 \\
\hline Learning Capability (LC) [112-114] (V.E $=65.87 \%)$ & \\
1 Factor: Commitment to learning (COMM) $(\alpha=0.91)$ & 0.81 \\
LC1. Use of mechanisms to spread knowledge widely & 0.79 \\
LC2. Analysis and studies carried out by the firm on other firms in the sector & 0.73 \\
LC3. Using experts (mentors) to develop employee learning (mentoring) & 0.72 \\
LC4. Employee involvement in continuous learning & 0.69 \\
LC5. Use of external information sources & 0.66 \\
LC6. Employee Consideration of Learning as an Investment & 0.64 \\
LC7. Attitude towards employee achievement & 0.58 \\
LC8. Organizational memory among the members of the firm & \\
2 Factor: Opening and experimentation (O\&E) $(\alpha=0.84)$ & 0.84 \\
LC9. Internal communication between firm members & 0.83 \\
LC10. Acceptance of suggestions or opinions & 0.76 \\
LC11. Interconnection between the different parts and/or departments of the firm & 0.58 \\
LC12. Experimentation in the firm & \\
3 Factor: No learning (-LEAR) ( $\alpha=0.60)$ & 0.81 \\
LC13. Employee Consideration of Learning as an Expense & 0.77 \\
LC14. Hierarchy among firm members & \\
\hline
\end{tabular}

Note: V.E = Variance explained; $\alpha=$ Cronbach's alpha; $\mathrm{N}=245$.

Cronbach's alpha ranges from 0 to 1 . The closer the alpha value is to 1 , the greater the internal consistency of the items analyzed. If the items are positively correlated then the variance of the sum of the items increases. Therefore, if the scores on all the items were identical, and therefore the scores would be perfectly correlated, the alpha value would be equal to 1 . On the other hand, if the items were completely independent, they show no type of relationship between them. The alpha value would be equal to 0 [130].

\section{Analysis and Results}

\subsection{Factor Analysis}

As this study considers a very broad diversity of literature, and the data were collected at the same time, a series of exploratory and confirmatory factors analyses (EFA/CFAs) were required in each construct [130].

The factor analysis provides a good fit. As Table 1 shows, KNOW consists of two factors, with 54.38 percent of explained variance; CREA consists of one factor, with 75.10 percent of explained variance; R\&D consists of one factor, with 90.85 percent of explained variance; PIP consists of one factor, with 73.69 percent of explained variance, and finally, LC consists of three factors, with 65.88 percent of explained variance. All loading factors are good because they are well above the threshold (0.45). Only one, TA6_KNOW, is below the threshold (0.44), and this time, it was not eliminated because it is very close to the threshold, and thus, maintain the agreement of the items on the scale.

Additionally, the CFA (first and second order) was needed to test the one-dimensionality of the measures within variables with different dimensions (KNOW and LC). For knowledge, the two-factor model recorded a good fit with the data $\left[\chi^{2} / \mathrm{df}=2.26\right.$; the Comparative Fit Index $(\mathrm{CFI})=0.97$; the Incremental Fit Index (IFI) $=0.97$; the Root Mean Squared Error of Approximation (RMSEA = 0.07] $(p<0.001)$. For LC, the two-factor model also recorded a good fit with the data $\left[\chi^{2} / \mathrm{df}=2.19 ; \mathrm{CFI}=0.96\right.$; 
IFI $=0.96$; RMSEA $=0.07](p<0.001)$. The CFA pattern supports the empirical distinctiveness of the variables.

It may be concluded that the items used to measure KNOW, CREA, R\&D, PIP and LC are suitable. They are also grouped into factors strongly related to TA_KNOW, EXP_KNOW, CREA, PIP and LC, consistent with the theoretical predictions proposed in this paper.

We used SEM to test the hypotheses, which is appropriate for this level of complexity.

\subsection{Structural Equation Modeling}

The normality of the factors referred to the dependent variables was verified (creativity and PIP). The assumptions that the residues of the relations must fulfill are, therefore, presumed. The study of normality was carried out using the Kolmogorov-Smirnov test, with satisfactory results.

The two types of knowledge (tacit and explicit) have a significant and positive effect on creativity (with a confidence level higher than 99\%). $\mathrm{H} 1$ and $\mathrm{H} 2$ are confirmed. In addition, creativity explains the results of PIP (with a confidence level of 95\%) and R\&D (with a confidence level of 90\%). H3a and $\mathrm{H} 3 \mathrm{~b}$, therefore, are also confirmed.

The results show that tacit knowledge is relevant to the direct development of PIP (with a confidence level of 99\%) and R\&D (with a confidence level of 95\%). H4a and H4b are therefore confirmed, and tacit knowledge leads the firm to an excellent PIP and R\&D. Tacit knowledge is the key ingredient of long-term innovation. On the other hand, the results confirm the major impact explicit knowledge has on PIP (with a confidence level of 95\%) and R\&D (with a confidence level of 99\%). This means $\mathrm{H} 5 \mathrm{a}$ and $\mathrm{H} 5 \mathrm{~b}$ are also confirmed.

In addition, the indices reveal a suitable overall fit for model 1 (knowledge, creativity, and PIP). The Chi-squared $\left(\chi^{2}\right)$ is 544.033 (degrees of freedom $=147, p=0.000$ ), $\chi^{2} / \mathrm{df}$ has a value of 3.701, and is not much higher than 3.0 [131]. The CFI is 0.894, and the Tucker-Lewis Index (TLI) is 0.862 . These scores are close to 0.9 , indicating a good fit. The RMSEA is 0.075 , less than 0.08 , and therefore indicates a good fit [132]. In turn, the indices also reveal a suitable overall fit for model 2 (knowledge, creativity, and R\&D). The Chi-squared $\left(\chi^{2}\right)$ is 543.341 (degrees of freedom $=147, p=0.000$ ), $\chi^{2} / \mathrm{df}$ has a value of 3.696. The CFI is 0.878 , and the TLI is 0.858 . These scores are close to 0.9 , indicating a good fit. The RMSEA is 0.077 , less than 0.08 , and therefore indicates a good fit. The results reflect a good fit for both models.

The SEM results are presented in Table 2 with standardized coefficients and the model's fit.

Table 2. Structural model fit, research hypotheses, and results.

\begin{tabular}{|c|c|c|c|c|c|c|}
\hline $\begin{array}{c}\text { Model 1: } \\
\text { KNOW-CREA-PIP }\end{array}$ & Paths & Estimate & SE & CR & $p$-value & Results \\
\hline $\mathrm{H} 1(+)$ & CREA $\leftarrow$ TA_KNOW & 0.491 & 0.066 & 7.435 & $* * *$ & Supported \\
\hline $\mathrm{H} 2(+)$ & CREA $\leftarrow$ EXP_KNOW & 0.396 & 0.114 & 3.462 & $* * *$ & Supported \\
\hline $\mathrm{H} 3 \mathrm{~A}(+)$ & $\mathrm{PIP} \leftarrow \mathrm{CREA}$ & 0.229 & 0.106 & 2.163 & $0.031 * *$ & Supported \\
\hline $\mathrm{H} 4 \mathrm{~A}(+)$ & $\mathrm{PIP} \leftarrow$ TA_KNOW & 0.341 & 0.100 & 3.402 & $* * *$ & Supported \\
\hline $\mathrm{H} 5 \mathrm{~A}(+)$ & $\mathrm{PIP} \leftarrow \mathrm{EXP} \_\mathrm{KNOW}$ & 0.399 & 0.151 & 2.637 & $0.008^{* *}$ & Supported \\
\hline \multicolumn{7}{|l|}{$\begin{array}{c}\text { Model 2: } \\
\text { KNOW-CREA-R\&D }\end{array}$} \\
\hline $\mathrm{H} 1(+)$ & CREA $\leftarrow$ TA_KNOW & 0.494 & 0.067 & 7.349 & $* * *$ & Supported \\
\hline $\mathrm{H} 2(+)$ & CREA $\leftarrow$ EXP_KNOW & 0.486 & 0.145 & 3.354 & $* * *$ & Supported \\
\hline Н3В (+) & $\mathrm{R} \& \mathrm{D} \leftarrow \mathrm{CREA}$ & 0.229 & 0.134 & 1.709 & $0.087 *$ & Supported \\
\hline $\mathrm{H} 4 \mathrm{~B}(+)$ & $\mathrm{R} \& \mathrm{D} \leftarrow \mathrm{TA} \_\mathrm{KNOW}$ & 0.025 & 0.121 & 2.098 & $0.036^{* *}$ & Supported \\
\hline H5B (+) & $\mathrm{R} \& \mathrm{D} \leftarrow \mathrm{EXP} \_\mathrm{KNOW}$ & 1.131 & 0.301 & 3.764 & $* * *$ & Supported \\
\hline
\end{tabular}


Table 2. Cont.

\begin{tabular}{|c|c|c|c|c|c|c|}
\hline $\begin{array}{c}\text { Model 1A: } \\
\text { KNOW-CREA-PIP } \\
\text { (LC1=LOW) }\end{array}$ & & & & & & \\
\hline $\mathrm{H} 1(+)$ & CREA $\leftarrow$ TA_KNOW & 0.477 & 0.485 & 0.983 & $0.326^{\mathrm{ns}}$ & Not Supported \\
\hline $\mathrm{H} 2(+)$ & CREA $\leftarrow$ EXP_KNOW & 0.236 & 0.162 & 1.458 & $0.145^{\mathrm{ns}}$ & Not Supported \\
\hline $\mathrm{H} 3 \mathrm{~A}(+)$ & $\mathrm{PIP} \leftarrow \mathrm{CREA}$ & 0.070 & 0.118 & 0.592 & $0.554^{\mathrm{ns}}$ & Not Supported \\
\hline $\mathrm{H} 4 \mathrm{~A}(+)$ & $\mathrm{PIP} \leftarrow$ TA_KNOW & 0.652 & 0.533 & 1.223 & $0.221^{\mathrm{ns}}$ & Not Supported \\
\hline $\mathrm{H} 5 \mathrm{~A}(+)$ & $\mathrm{PIP} \leftarrow \mathrm{EXP} \_\mathrm{KNOW}$ & 0.318 & 0.180 & 1.762 & $0.078 *$ & Supported \\
\hline \multicolumn{7}{|l|}{$\begin{array}{c}\text { Model 1B: } \\
\text { KNOW-CREA-PIP } \\
\text { (LC2=HIGH) }\end{array}$} \\
\hline $\mathrm{H} 1(+)$ & CREA $\leftarrow$ TA_KNOW & 0.223 & 0.075 & 2.989 & $0.003^{* *}$ & Supported \\
\hline $\mathrm{H} 2(+)$ & $\mathrm{CREA} \leftarrow$ EXP_KNOW & 0.475 & 0.213 & 2.236 & $0.025^{* *}$ & Supported \\
\hline $\mathrm{H} 3 \mathrm{~A}(+)$ & $\mathrm{PIP} \leftarrow \overline{\mathrm{CREA}}$ & 0.094 & 0.239 & 0.394 & $0.693^{\mathrm{ns}}$ & Not Supported \\
\hline $\mathrm{H} 4 \mathrm{~A}(+)$ & $\mathrm{PIP} \leftarrow$ TA_KNOW & 0.414 & 0.133 & 3.106 & $0.002 * *$ & Supported \\
\hline $\mathrm{H} 5 \mathrm{~A}(+)$ & $\mathrm{PIP} \leftarrow \mathrm{EXP} \_\mathrm{KNOW}$ & 0.513 & 0.347 & 1.480 & $0.139^{\mathrm{ns}}$ & Not Supported \\
\hline \multicolumn{7}{|l|}{$\begin{array}{l}\text { Model 2A: } \\
\text { KNOW-CREA-R\&D } \\
\text { (LC1=LOW) }\end{array}$} \\
\hline $\mathrm{H} 1(+)$ & CREA $\leftarrow$ TA_KNOW & 0.466 & 0.479 & 0.973 & $0.331^{\mathrm{ns}}$ & Not Supported \\
\hline $\mathrm{H} 2(+)$ & CREA $\leftarrow$ EXP_KNOW & 0.561 & 0.329 & 1.707 & $0.088 *$ & Supported \\
\hline Н3В (+) & $R \& D \leftarrow C R E A$ & 0.330 & 0.213 & 1.550 & $0.121^{\mathrm{ns}}$ & Not Supported \\
\hline H4B (+) & R\&D $\leftarrow$ TA_KNOW & 1.309 & 0.952 & 1.376 & $0.169^{\mathrm{ns}}$ & Not Supported \\
\hline $\mathrm{H} 5 \mathrm{~B}(+)$ & $\mathrm{R} \& \mathrm{D} \leftarrow \mathrm{EXP} \_\mathrm{KNOW}$ & 1.092 & 0.596 & 1.833 & $0.067 *$ & Supported \\
\hline \multicolumn{7}{|l|}{$\begin{array}{c}\text { Model 2B: } \\
\text { KNOW-CREA-R\&D } \\
\text { (LC2 = HIGH) }\end{array}$} \\
\hline $\mathrm{H} 1(+)$ & CREA $\leftarrow$ TA_KNOW & 0.256 & 0.081 & 3.172 & $0.002 * *$ & Supported \\
\hline $\mathrm{H} 2(+)$ & CREA $\leftarrow$ EXP_KNOW & 0.602 & 0.266 & 2.259 & $0.024^{* *}$ & Supported \\
\hline H3B (+) & $\mathrm{R} \& \mathrm{D} \leftarrow \mathrm{CREA}$ & 0.665 & 0.493 & 1.349 & $0.177^{\mathrm{ns}}$ & Not Supported \\
\hline $\mathrm{H} 4 \mathrm{~B}(+)$ & $\mathrm{R} \& \mathrm{D} \leftarrow \mathrm{TA} \_\mathrm{KNOW}$ & 0.382 & 0.197 & 1.934 & $0.053 *$ & Supported \\
\hline $\mathrm{H} 5 \mathrm{~B}(+)$ & $\mathrm{R} \& \mathrm{D} \leftarrow \mathrm{EXP} \_\mathrm{KNOW}$ & 2.200 & 1.056 & 2.084 & $0.037^{* *}$ & Supported \\
\hline
\end{tabular}

\subsection{Structural Equation Modeling with Learning Capability as Moderator}

Table 2 shows the results of the structural model with the effects of learning capability as a moderator between (1) knowledge, creativity, and PIP, and (2) knowledge, creativity, and R\&D.

The strength of employees with a high level of learning capability is very important for the firm. Employees that show, channel, analyze, and transmit their knowledge are successful in innovation. A multi-group moderation analysis was performed in SEM, with a distinction being made between collaborators with high learning capability $(\mathrm{N}=179)$ and those with low learning capability $(\mathrm{N}=66)$. Learning capability enhances and strengthens most of the relationships between knowledge, creativity, PIP, and R\&D. H6a and H6b are therefore largely fulfilled, so this is confirmed.

The indices with learning capability have an adequate overall fit for model 1A (knowledge, creativity, PIP, and learning capability moderator). The $\chi^{2}$ is 676.569 (degrees of freedom $=294$, $p=0.000), \chi^{2} / \mathrm{df}$ has a value of 2.301 . The CFI is 0.850 , and the TLI is 0.873 . These scores are close to 0.9 , which indicates a good fit. The RMSEA is 0.073 , less than 0.08 , and therefore indicates a good fit. In turn, the indices also reveal a suitable overall fit for model 2A (knowledge, creativity, R\&D, and learning capability moderator). The $\chi^{2}$ is 668.807 (degrees of freedom $=294, p=0.000$ ), $\chi^{2} / \mathrm{df}$ has a value of 2.275 . The CFI is 0.851 , and the TLI is 0.827 . The RMSEA is 0.073 . The results indicate a good fit for both models.

The SEM results are presented in Figure 2 with standardized path coefficients. 


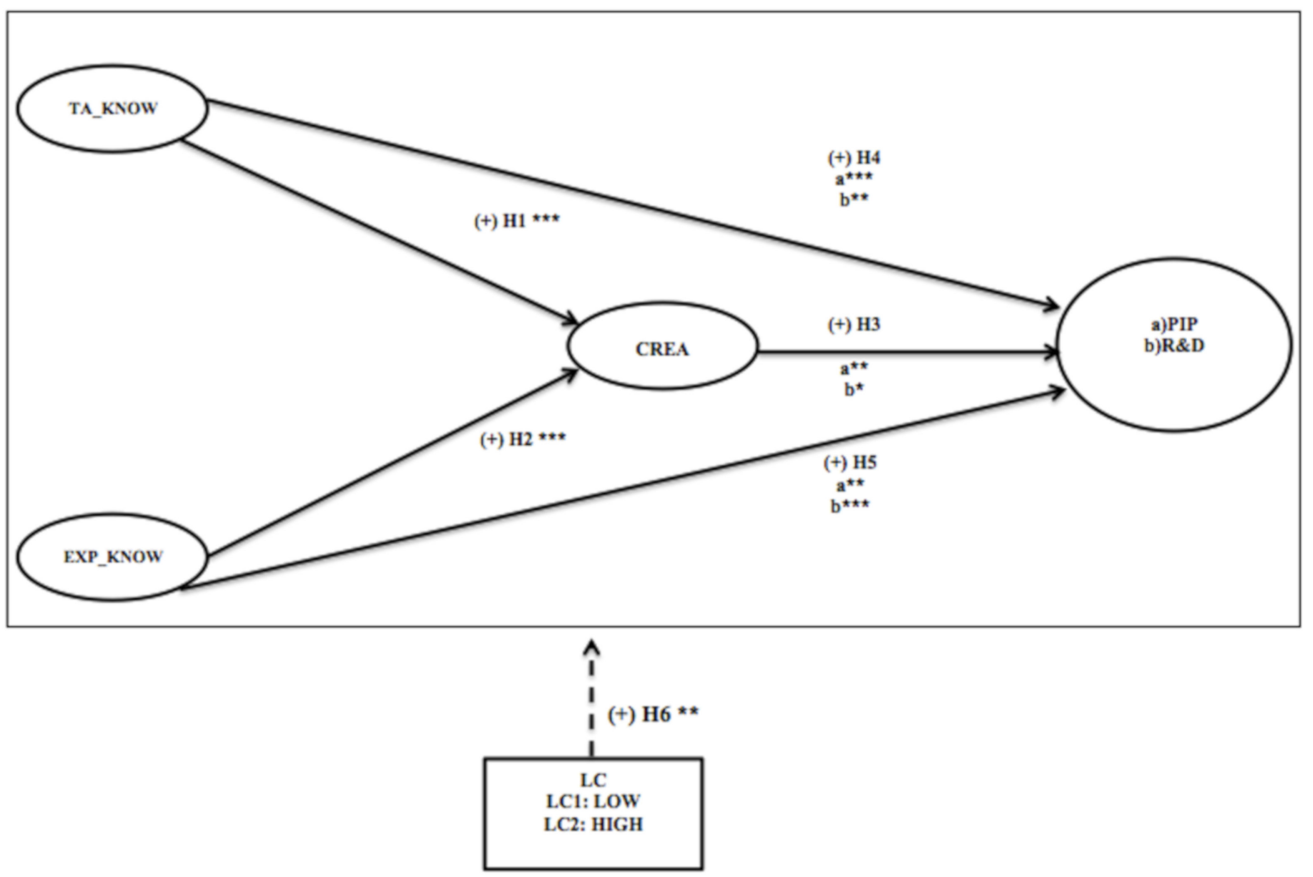

Figure 2. The final structural model predicting sustainable product innovation performance and research and development.

\section{Discussion and Conclusions}

Many scholars and managers have emphasized the relevancy of knowledge in firms. Knowledge can represent a driving force for the adoption of new innovate practices into firms. However, few studies have examined the relationships between tacit knowledge, creativity and PIP and R\&D [1]. The aim of this study is to answer four research questions: (1) Can employees develop new ideas through the management of ambidextrous knowledge? (2) Can firms develop new R\&D projects through the management of ambidextrous knowledge? (3) Can firms improve sustainable product innovation performance through the management of ambidextrous knowledge? (4) Can learning capability influence $R \& D$ and PIP?

Furthermore, this study examined: (a) The impact of tacit knowledge and explicit knowledge on creativity; (b) the impact of creativity on PIP and R\&D; and (c) the impact of tacit knowledge and explicit knowledge directly on PIP and R\&D.

The results show that ambidextrous knowledge positively impacts creativity, PIP and R\&D [63,71,77]. They also support the moderating role of LC, which significantly improves the explanatory power of the model. Firms with a higher level of learning capability are relative to the implementation of tacit and explicit knowledge in firms, which facilitates the adoption of new ideas, sustainable product innovation performance, and $R \& D[58,99,102]$. The results also show that tacit knowledge is an important antecedent for the development of creativity and PIP [66-71].

In summary, ambidextrous knowledge is a very powerful driving-force for generating new ideas, and consequently, successfully launching a new product or implementing a new research project. The results shed light on relevant issues, so far unidentified, for understanding knowledge management in relation to innovation in the firm [133]. First, we analyzed knowledge management from an ambidextrous perspective, distinguishing from the viewpoints of exploration or exploitation. This is a significant contribution, as these types of knowledge can operate differently. Accordingly, knowledge has been divided into tacit and explicit knowledge. Second, we analyzed the effect of an extraordinary capability, such as learning capability, confirming its major influence on PIP and R\&D. This capability helps to garner, absorb and digest knowledge more easily. This can strengthen the relationships between knowledge, creativity, PIP and R\&D [102]. 


\subsection{Theoretical Contributions}

Some studies have dealt with the study of human resources and innovation in an overall and aggregate manner $[134,135]$. However, this study goes a step further by focusing on ambidextrous knowledge as a source of creativity, PIP, and R\&D. There are fewer studies that have sought to measure and analyze tacit knowledge. One reason may be the high cost of obtaining information related to employees' innermost aspects. Researchers should pay more theoretical and empirical attention to this construct from an ambidextrous perspective. It is one of the true architects of innovation within the firm firms.

In addition, this study provides new evidence that underscores the importance of carrying out multi-group analyses in knowledge and innovation studies. In this vein, the model not only analyzes direct links between knowledge, creativity, PIP, and R\&D, as it also includes a multi-group analysis on SEM with the moderating effect of learning capability.

This study contributes to the literature based on the KBV and the Ambidexterity Organizations Approach. Collaborators with both types of knowledge will lead to a greater development of novel ideas, and consequently, innovative results. The study also contributes to other approaches, such as the DCV. The model includes employees' most dynamic environments to support and strengthen the effects initially raised between knowledge, creativity, PIP, and R\&D. It also contributes to Evolutionary Theory.

Individual variables within the organization have not been studied in great detail, as creativity is a factor that arises from individuals. This study introduces individual creativity into its model for two reasons: (1) It will be the first variable that reflects the effects of the accumulation and management of knowledge; and (2) it will be the first clear antecedent of the development of PIP and R\&D.

\subsection{Managerial Contributions}

There are many knowledge management tools available to firm managers. It is therefore necessary to analyze which is more suitable for promoting innovation activity more forcefully. Leaders and managers will look to ambidextrous knowledge to identify successful innovation at all times.

This study helps leaders and managers understand the relevance of the accumulation and management of explicit knowledge, as the most tangible part of knowledge, but also the development of tacit knowledge and dynamic or intangible capabilities, which emerge from employees' culture, values, and past experience. They are powerful drivers of innovation and long-term value creation.

One of the biggest challenges managers face is how to marshal employees to contribute all their internal value to the organization. Managing the accumulation of explicit knowledge can be easier, and can be done through specific training. But how can we ensure employees contribute all their experience and training to the organization? How can we make employees see training as a tool for both professional and personal development? This study contends that managers must guarantee the development of the learning capability as a boost for "extraordinary" innovation results, and they can use training tools and career development plans to help reinforce this capability in their employees.

Leaders and managers should be aware that the resources and efforts dedicated to the development of creativity and learning capability cannot be considered a cost, but instead as a long-term investment to be performed continuously as a way of entering the spiral of innovation and becoming pioneers when setting trends within the firm's field or markets. Leaders and managers should pay special attention to employees to know where to direct learning efforts [136].

We take the example of Finland, which is one of the most advanced nations in teaching and learning for the development and use of information and communication technologies. How has this nation become a leader in innovation? This achievement is explained by the adoption of a cutting-edge initiative that aims to direct the efforts derived from knowledge and education towards the development of new products and services. Therefore, our results in the Spanish context support the successful example of Finland, and shed light on how our model would be applied in other contexts if firms decided to commit to knowledge and innovation as two main strategic assets [137]. 
Finally, we provide four relevant practical recommendations and implementation guidelines for Small and Medium Enterprises:

1. Ambidextrous knowledge for R\&D and innovation:

* The willingness of managers to support new exploration and exploitation activities. For example, managers can develop new activities to implement new projects and products in firms related to one type of knowledge or another, depending on the need or knowledge and preferences of their employees.

* Attendance of congresses, fairs and meetings to garner new knowledge. The active participation of employees in this type of event can open their minds and make them become more proactive in implementing new tools and methodologies within the firm.

* Joint innovation projects with employees oriented toward exploration and exploitation activities. Although it is appropriate to identify the type of knowledge necessary in each phase of the innovative process, we must bear in mind that both types of knowledge are closely related and that they interact together on many occasions to give us a unique and innovative result.

2. Investment and training in new HR practices for innovation:

* Courses and training. Continuous training of employees within the firm is the greatest symbol of good human resource management, and therefore, of innovation. A firm that innovates must give continuous training to its workers and recollect itself if it wants to obtain a sustainable competitive advantage.

* Engaging employees' trust and motivation for developing new ideas. Much of the knowledge that employees possess depends on their inner, most personal part, such as tacit knowledge. Therefore, it is very important to create a climate of trust and motivation with employees so that they can feel comfortable learning, translate their knowledge into new ideas or share them with their colleagues.

* Creation of a culture that encourages creativity and innovation. It is possible that if there is a climate of trust and motivation within the firm, it is easier to implement a culture of creativity and innovation, that is, where it is allowed to make mistakes that allow us to grow and advance as people and as an organization.

* The introduction of norms and behaviors that encourage creativity and innovation. In addition, if the firm implements standards and guidelines of conduct that require compliance, it will be easier to achieve innovative success.

3. Fast learning capability for innovation:

* Climate for learning and experimentation. Firms that foster a climate of learning and experimentation will guide the training of their employees as an investment or a long-term process. This favors the culture of continuous innovation.

* Encouragement for taking risks in new product development. In addition, firms that encourage their employees to take risks and new challenges will be achieving continuous learning in which they will gain knowledge whether they are successful or not in innovation results.

* Teamwork and effective communication. For the exchange, interaction and effective implementation of employee knowledge, it is very important that the firm encourages teamwork and communication. Communication is an effective tool to improve and develop new projects and products.

* Involvement of employees in important decisions. In addition, if the firm offers security, autonomy and responsibility to its employees so that they can be part of decision-making, 
this will make the application of training and knowledge faster, more effective and voluntary. "If we are part of the decision we will also be part of the solution".

4. New ideas for R\&D and innovation:

* Reinforcement of information sharing. Generating a work environment where employees share information. For example, meeting rooms, breaks, etc.

* Creation of a culture that encourages tacit knowledge and explicit knowledge. Giving the appropriate value to both types of knowledge according to the type of employees and the stage of the innovative process.

* $\quad$ Encouragement for employees to share their knowledge and ideas. Firms can design compensation mechanisms for those employees who train, help and share their knowledge.

* Support for networking among employees. Firms can design physical and electronic networks where their employees can have time within their working day to exchange options, information, learning, knowledge, experiences, ideas, etc.

In short, this study invites the business community to identify the effects that can be derived from ambidextrous knowledge, creativity, and learning capability. It may lead to extraordinary innovation results within the organization.

\subsection{Limitations and Future Research}

Although this study uses different information sources (primary and secondary), therefore largely eliminating the risk of bias from the use of a single source "Common Method Bias", the variables used are based on perceptual measures-which means a certain degree of subjectivity may be introduced. Use could be made of other measurement scales already validated in other disciplines, such as psychology. This is already done here to measure constructs, such as creativity. It can be considered as a possible way of improving other constructs, together with the extension of a double data collection to include two informants (employees and managers).

Our analysis focuses only on firms that have received CDTI funding. It would be necessary to apply the model to a range of firms that do not meet this requirement in order to carry out comparative studies and identify the reasons some firms obtain higher or lower innovation results. This will also allow including new sectors and countries [138].

Regarding the methodological section, the model can be analyzed using other qualitative analysis techniques, such as fuzzy-set qualitative comparative analysis (fsQCA). The use of mixed methods encourages the study and interpretation of more comprehensive results within complex models $[60,83,85]$.

Finally, this study is based on a three-year period in which the firms obtained funding for R\&D projects $(2017,2018$, and 2019). Nevertheless, it would be convenient to explore the model over a longer period, and could be enriched by time lags. This is noteworthy because it would take into account the time elapsed since the leader or manager invested in knowledge through to the launch of new products or projects.

Author Contributions: Conceptualization, L.M.-P. and J.G.; methodology, L.M.-P. and J.G.; software, L.M.-P.; validation, L.M.-P. and J.G.; formal analysis, L.M.-P.; investigation, L.M.-P. and J.G.; data curation, L.M.-P.; writing —original draft preparation, L.M.-P.; writing—review and editing, L.M.-P. and J.G.; visualization, L.M.-P. and J.G.; supervision, J.G.; project administration, J.G.; funding acquisition, L.M.-P. and J.G. All authors have read and agree to the published version of the manuscript.

Funding: This research was funded by "Agencia Estatal de Investigación" (AEI) and the "Fondo Europeo de Desarrollo Regional" (FEDER), grant number ECO16-76876-R-AEI/FEDER, UE.

Conflicts of Interest: The authors declare no conflict of interest. 


\section{References}

1. Easterby-Smith, M.; Prieto, I.M. Dynamic capabilities and knowledge management: An integrative role for learning? Br. J. Manag. 2008, 19, 235-249. [CrossRef]

2. Du Plessis, M. The role of knowledge management in innovation. J. Knowl. Manag. 2007, 11, 20-29. [CrossRef]

3. Helms, R.W. Redesigning communities of practice using knowledge network analysis. In Hands-On Knowledge Co-Creation and Sharing: Practical Methods and Techniques; Kazi, A., Wohlfart, L., Wolf, P., Eds.; Knowledge Board Community: Stuttgart, Germany, 2007; pp. 253-273.

4. Sung, S.Y.; Choi, J.N. Effects of team knowledge management on the creativity and financial performance of organizational teams. Organ. Behav. Hum. Decis. Process 2012, 118, 4-13. [CrossRef]

5. Kianto, A.; Waajakoski, J. Linking social capital to organizational growth. Knowl. Manag. Res. Pract. 2010, 8, 4-14. [CrossRef]

6. Andreeva, T.; Kianto, A. Does knowledge management really matter? Linking KM practices, competitiveness and economic performance. J. Knowl. Manag. 2012, 16, 617-636. [CrossRef]

7. Miles, R.; Snow, C. Fit, Failure and the Hall of Fame; Free Press: New York, NY, USA, 1994.

8. Gratton, L.; Ghoshal, S. Managing Personal Human Capital: New Ethos for the Volunteer' Employee. Eur. Manag. J. 2003, 21, 1-10. [CrossRef]

9. Dibrell, C.; Craig, J.B.; Kim, J.; Johnson, A.J. Establishing How Natural Environmental Competency, Organizational Social Consciousness, and Innovativeness Relate. J. Bus. Ethics. 2015, 127, 591-605. [CrossRef]

10. Kennedy, E.B.; Marting, T.A. Biomimicry Streamlining the Front End of Innovation for Environmentally. Sustainable Products. Res. Technol. Manag. 2016, 59, 40-47. [CrossRef]

11. Gasbarro, F.; Annunziata, E.; Rizzi, F.; Frey, M. The Interplay between Sustainable Entrepreneurs and Public Authorities: Evidence from Sustainable Energy Transitions. Organ. Environ. 2017, 30, 226-252. [CrossRef]

12. Vollenbroek, F.A. Sustainable Development and the Challenge of Innovation. J. Clean. Prod. 2002, 10, $215-223$. [CrossRef]

13. Wu, G.C. Effects of Socially Responsible Supplier Development and Sustainability-Oriented Innovation on Sustainable Development: Empirical Evidence from SMEs. Corp. Soc. Responsib. Environ. Manag. 2017, 24, 661-675. [CrossRef]

14. Nonaka, I.; Konno, N. The concept of "Ba": Building a foundation for Knowledge Creation. Calif. Manag. Rev. 1998, 40-54, 43. [CrossRef]

15. Herschel, R.T.; Nemati, H.; Steiger, D. Tacit to explicit knowledge conversion: Knowledge exchange protocols. J. Knowl. Manag. 2001, 5, 107-116. [CrossRef]

16. Nonaka, L.; Takeuchi, H.; Umemoto, K. A theory of organizational knowledge creation. Int. J. Technol. Manag. 1996, 11, 833-845.

17. Astorga-Vargas, M.A.; Flores-Rios, B.L.; Licea-Sandoval, G.; Gonzalez-Navarro, F.F. Explicit and tacit knowledge conversion effects, in software engineering undergraduate students. Knowl. Manag. Res. Pract. 2017, 15, 336-345. [CrossRef]

18. Caniëls, M.C.J.; Kronenberg, K.; Werker, C. Conceptualizing Proximity in Research Collaborations between Universities and Firms. In The Social Dynamics of Innovation Networks; Rutten, R., Benneworth, P., Irawati, D., Boekema, F., Eds.; Routledge: Abingdon, UK, 2014; pp. 221-238.

19. Gibson, C.B.; Birkinshaw, J. The Antecedents, Consequences and Mediating Role of Organizational Ambidexterity. Acad. Manag. J. 2004, 47, 209-226.

20. Brusoni, S.; Rosenkranz, N.A. Reading between the Lines: Learning as a Process between Organisational Context and Individuals' Proclivities. Eur. Manag. J. 2014, 32, 147-154. [CrossRef]

21. Jansen, J.J.; Kostopoulos, K.C.; Mihalache, O.R.; Papalexandris, A. A Sociopsychological Perspective on Team Ambidexterity: The Contingency Role o Supportive Leadership Behaviours. J. Manag. Stud. 2016, 53, 939-965. [CrossRef]

22. Alghamdi, F. Ambidextrous Leadership, Ambidextrous Employee and the Interaction between Ambidextrous Leadership and Employee Innovative Performance. J. Innov. Entrep. 2018, 7, 1-14. [CrossRef]

23. Torrance, E.P. The Torrance Tests of Creative Thinking-Norms-Technical Manual Research Edition-Verbal Tests, Forms A and B-Figural Tests, Forms A and B; Personnel Press: Princeton, NJ, USA, 1974.

24. Barney, J.B. Looking Inside for Competitive Advantage. Acad. Manag. Exec. 1995, 9, 49-61. [CrossRef] 
25. Marín-Idárraga, D.A.; Hurtado-González, J.M.; Cabello-Medina, C. The Antecedents of Exploitation-Exploration and their Relationship with Innovation: A Study of Managers'Cognitive Maps. Creat. Innov. Manag. 2016, 25, 18-37. [CrossRef]

26. Dosi, G. Perspectives on Evolutionary Theory. Sci. Public Policy 1991, 18, 353-361. [CrossRef]

27. Grant, R.M. The Resource-Based Theory of Competitive Advantage: Implications for Strategy. Calif. Manag. Rev. 1991, 33, 114-135. [CrossRef]

28. Itami, H. Mobilizing Invisible Assets; Harvard University Press: Cambridge, MA, USA, 1987.

29. Prahalad, C.K.; Hamel, H. The Core Competence of the Corporation. Harv. Bus. Rev. 1990, 68, 79-91.

30. Spender, J.C. Knowledge and the Firm: Overview. Strateg. Manag. J. 1996, 17, 5-9. [CrossRef]

31. Grant, R.M.; Baden-Fuller, C. A Knowledge Assessing Theory o Strategic Alliances. J. Manag. Stud. 2004, 41,61-84. [CrossRef]

32. Nonaka, I. A Dynamic Theory of Organizational Knowledge Creation. Organ. Sci. 1994, 39, 1245-1264. [CrossRef]

33. Duncan, P. The ambidextrous organization: Designing dual structures for innovation. In The Management of Organization; Kilmann, R.H., Pondy, L.R., Slevin, D., Eds.; North-Holland Publ.: New York, NY, USA, 1976; Volume 1, pp. 167-188.

34. Jarzabkowski, J.; Smets, M.; Bednarek, R.; Burke, G.; Spee, P. Institutional Ambidexterity: Leveraging institutional complexity in practice. In Institutional Logics in Action, Part B (Research in the Sociology of Organizations); Lounsbury, M., Boxenbaum, E., Eds.; Emerald Group Publishing Limited: Bingley, UK, 2013; Volume 39, pp. 37-61.

35. Caniëls, M.C.J.; Veld, M. Employee ambidexterity, high performance work systems and innovative work behaviour: How much balance do we need? Int. J. Hum. Resour. Manag. 2019, 30, 565-585. [CrossRef]

36. Rogan, M.; Mors, M.L. A Network Perspective on Individual-level Ambidexterity in Organizations. Organ. Sci. 2014, 25, 1860-1877. [CrossRef]

37. Birkinshaw, J.; Zimmermann, A.; Raisch, S. How do Firms Adapt to Discontinuous Change? Bridging the Dynamic Capabilities and Ambidexterity Perspectives. Calif. Manag. Rev. 2016, 58, 36-58. [CrossRef]

38. Levinthal, D.A.; March, J.G. The Myopia of Learning. Strateg. Manag. J. 1993, 14, 95-112. [CrossRef]

39. Halevi, M.Y.; Carmeli, A.; Brueller, N. Ambidexterity in SBUs: TMT Behavioral Integration and Environmental dynamism. Hum. Resour. Manag. 2015, 54, 223-238. [CrossRef]

40. Turner, N.; Kutsch, E.; Leybourne, S.A. Rethinking Project Reliability using the Ambidexterity and Mindfulness Perspectives. Int. J. Manag. Proj. Bus 2016, 9, 845-864. [CrossRef]

41. Teece, D.J.; Pisano, G.; Shuen, A. Dynamic Capabilities and Strategic Management. Strateg. Manag. J. 1997, 18, 509-533. [CrossRef]

42. Eisenhardt, K.M.; Martin, J.A. Dynamic Capabilities: What Are They? Strateg. Manag. J. 2000, $21,1105-1121$. [CrossRef]

43. Song, M.; Droge, C.; Hanvanich, S.; Calantone, R. Marketing and Technology Resource Complementary: An Analysis of Their Interaction Effect in Two Environmental Contexts. Strateg. Manag. J. 2005, 26, 259-276. [CrossRef]

44. Martín, G.; García, F.E. Hacia una Visión Integradora del Capital Intelectual de las Organizaciones. Concepto y Componentes; Boletín Económico de ICE: Madrid, Spain, 2003; Volume 2756, pp. 7-16.

45. Metcalfe, S. The economic foundations of technology policy: Equilibrium and evolutionary perspectives. In Handbook of the Economics of Innovation and Technological Change; Stoneman, P., Ed.; Blackwell: Oxford, UK, 1995; pp. 409-512.

46. Schumpeter, J.A. The Theory of Economic Development; Harvard University Press: Cambridge, MA, USA, 1934.

47. Schumpeter, J.A. Capitalism, Socialism and Democracy; Harper: New York, NY, USA, 1942.

48. OCDE. Guidelines for Collecting and Interpreting Innovation Data. In Manual de Oslo, 3rd ed.; OCDE: Paris, France, 2006.

49. Wang, C.L.; Ahmed, P.K. The Development and Validation of the Organisational Innovativeness Construct using Confirmatory Factor Analysis. Eur. J. Innov. Manag. 2002, 7, 303-313. [CrossRef]

50. Cohen, W.M.; Levinthal, D.A. Absorptive Capacity: A New Perspective on Learning and Innovation. Adm. Sci. Q. 1990, 35, 128-152. [CrossRef]

51. Valgeirsdottir, D.; Onarheim, B. Studying Creativity Training Programs: A Methodological Analysis. Creat. Innov. Manag. 2017, 26, 430-439. [CrossRef] 
52. OCDE. Guidelines for Collecting and Reporting Data on Research and Experimental Development. In Manual de Frascati; OCDE: Paris, France, 2015.

53. Bueno, E. Organización de Empresas. In Estructura, Procesos y Modelos; Pirámide: Madrid, Spain, 1996.

54. Muñoz-Pascual, L.; Curado, C.; Galende, J. Human Resource Management Contributions to Knowledge Sharing for a Sustainability-Oriented Performance: A Mixed Methods Approach. Sustainability 2020, $12,161$. [CrossRef]

55. Zhou, J.; Shalley, C.E. Research on Employee Creativity: A Critical Review and Directions for Future Research. In Research in Personnel and Human Resource Management; Martocchio, J., Ed.; Elsevier: Oxford, UK, 2003; pp. 165-217.

56. Kremer, H.; Villamor, I.; Aguinis, H. Innovation Leadership: Best-practice Recommendations for Promoting Employee Creativity, Voice, and Knowledge Sharing. Bus. Horiz. 2019, 62, 65-74. [CrossRef]

57. Zollo, M.; Winter, S.G. Deliberate Learning and the Evolution of Dynamic Capabilities. Organ. Sci. 2002, 13, 339-351. [CrossRef]

58. Alegre, J.; Chiva, R. Assessing the Impact of Organizational Learning Capability on Product Innovation Performance: An Empirical Test. Technovation 2008, 28, 315-326. [CrossRef]

59. Ye, Q.; Wang, D.; Li, X. Promoting Employees' Learning from Errors by Inclusive Leadership: Do Positive Mood and Gender Matter? Balt. J. Manag. 2018, 13, 125-142. [CrossRef]

60. Muñoz-Pascual, L.; Curado, C.; Galende, J. The Triple Bottom Line on Sustainable Product Innovation Performance in SMEs: A Mixed Methods Approach. Sustainability 2019, 11, 1689. [CrossRef]

61. Tallott, M.; Hilliard, R. Developing Dynamic Capabilities for Learning and Internationalization: A Case Study of Diversification in an SME. Balt. J. Manag. 2016, 11, 328-347. [CrossRef]

62. Jiménez-Jiménez, D.; Martínez-Costa, M.; Sanz-Valle, R. Knowledge management practices for innovation: A multinational corporation's perspective. J. Knowl. Manag. 2014, 18, 905-918. [CrossRef]

63. Leiponen, A. Managing Knowledge for Innovation: The Case of Business-to-business Services. J. Prod. Innov. Manag. 2006, 23, 238-258. [CrossRef]

64. Garud, R. On the Distinction between Know-how, Know-why, and Know-what. In Advances in Strategic Management; JAI Press: Greenwich, CT, USA, 1997; Volume 14, pp. 81-101.

65. Soto-Acosta, P.; Del Giudice, M.; Scuotto, V. Emerging Issues on Business Innovation Ecosystems: The Role of Information and Communication Technologies (ICTs) for Knowledge Management (KM) and Innovation within and Among Enterprises. Balt. J. Manag. 2018, 13, 298-302. [CrossRef]

66. González-Álvarez, N.; Nieto-Antolín, M. Appropriabilty of Innovation Results: An Empirical Study in Spanish Manufacturing Firms. Technovation 2007, 27, 280-295. [CrossRef]

67. Oyemomi, O.; Liu, S.; Neaga, I.; Alkhuraiji, A. How Knowledge Sharing and Business Process Contribute to Organizational Performance: Using the fsQCA Approach. J. Bus. Res. 2016, 69, 5222-5227. [CrossRef]

68. Osabutey, E.L.C.; Jin, Z. Factors Influencing Technology and Knowledge Transfer: Configurational Recipes for Sub-Saharan Africa. J. Bus. Res. 2016, 69, 5390-5395. [CrossRef]

69. Groza, M.D.; Locander, D.A.; Howlett, C.H. Linking Thinking Styles to Sales Performance: The Importance of Creativity and subjective knowledge. J. Bus. Res. 2016, 69, 4185-4193. [CrossRef]

70. Cheng, L.Y.; Cai, H.; Jin, Z. The Effect of Parental Opportunism, IJV's Autonomy and Tacit Knowledge on IJV Instability: A Comparison of Multi-variante Regression and fuzzy-set Qualitative Comparative Analysis. J. Bus. Res. 2016, 69, 5203-5209. [CrossRef]

71. Muñoz-Pascual, L.; Galende, J. The Impact of Knowledge and Motivation Management on Creativity: Employees of Innovative Spanish Companies. Empl. Relat. 2017, 39, 732-752. [CrossRef]

72. Hayton, J.C. Competing in the New Economy: The Effect of Intellectual Capital on Corporate Entreprenerurship in High-Technology New Ventures. RED Manag. 2005, 35, 137-155.

73. Paton, S. Introducing Taylor to the Knowledge Economy. Empl. Relat. 2012, 35, 20-38. [CrossRef]

74. Taggar, S. Individual Creativity and Group Ability to Utilize Individual Creative Resources: A Multilevel Model. Acad. Manag. J. 2002, 45, 315-330.

75. Dyer, L.; Shafer, R. From Human Resource Strategy to Organizational Effectiveness: Lessons from Research on Agile Organizations. In Research in Personnel and Human Resource Management (Supplement 4: Strategic Human Resource Management in the 21st Century); Wright, P., Dyer, L., Boudreau, J., Milkovich, G., Eds.; JAI Press: Stamford, CT, USA, 1999; pp. 145-174. 
76. Van de Ven, A.H. Central Problems in the Management of Innovation. Manag. Sci. 1986, 32, 590-607. [CrossRef]

77. Amabile, T.M.; Barsade, S.; Mueller, J.; Staw, B. La Conexión entre las Emociones y la Creatividad en el Trabajo. Harv. Deusto Bus. Rev. 2007, 159, 36-44.

78. Amabile, T.M.; Conti, R.; Coon, H.; Lazenby, J.; Herron, M. Assessing the work environment for creativity. Acad. Manag. J. 1996, 39, 1154-1184.

79. Dennis, C.; Brakus, J.J.; Gupta, S.; Alamanos, E. The effect of digital signage on shoppers' behavior: The role of the evoked experience. J. Bus. Res. 2014, 67, 2250-2257. [CrossRef]

80. Díaz-Chao, A.; Sainz-González, J.; Torrent-Sellens, J. ICT, innovation, and firm productivity: New evidence from small local firms. J. Bus. Res. 2015, 68, 1439-1444. [CrossRef]

81. Fossas-Olalla, M.; Minguela-Rata, B.; López-Sánchez, J.I.; Fernández-Menéndez, J. Product innovation: When should suppliers begin to collaborate? J. Bus. Res. 2015, 68, 1404-1406. [CrossRef]

82. Cheng, C.F.; Chang, M.L.; Li, C.S. Configural paths to successful product innovation. J. Bus. Res. 2013, 66, 2561-2573. [CrossRef]

83. Curado, C.; Muñoz-Pascual, L.; Galende, J. Antecedents of Innovation Performance in SMEs: A Mixed Methods Approach. J. Bus. Res. 2018, 39, 206-215. [CrossRef]

84. Heffernan, M.; Harney, B.; Cafferkey, K.; Dundon, T. Exploring the HRM-Performance Relationship: The Role of Creativity Climate and Strategy. Empl. Relat. 2016, 38, 438-462. [CrossRef]

85. Muñoz-Pascual, L.; Curado, C.; Galende, J. How does the use of information technologies affect the adoption of environmental practices in SMEs? A mixed-methods approach. Rev. Manag. Sci. 2019, 1-28. [CrossRef]

86. Ujwary-Gil, A. The Business Model and Intellectual Capital in the Value Creation of Firms: A Literature Review. Balt. J. Manag. 2017, 12, 368-386. [CrossRef]

87. Edvinsson, L.; Sullivan, P. Developing a Model for Managing Intellectual Capital. Eur. Manag. J. 1996, 14, 356-364. [CrossRef]

88. García-Morales, V.J.; Martín-Rojas, R.; Lardón-López, M.E. Influence of Social Media Technologies on Organizational Performance through Knowledge and Innovation. Balt. J. Manag. 2018, 13, 345-367. [CrossRef]

89. Tödtling, F.; Lehner, P.; Kaufmann, A. Do Different Types of Innovation Rely on Specific Kinds of Knowledge Interactions? Technovation 2009, 29, 59-71. [CrossRef]

90. McEvily, S.K.; Das, S.; McAbe, K. Avoiding Competence Substitution through Knowledge Sharing. Acad. Manag. Rev. 2000, 25, 294-311. [CrossRef]

91. Hegde, D.; Shapira, P. Knowledge, Technology Trajectories, and Innovation in a Developing Country Context: Evidence from a Survey of Malaysian Firms. Int. J. Technol. Manag. 2007, 40, 349-370. [CrossRef]

92. Pizarro, I.; Real, J.C.; De la Rosa, M.D. El Papel del Capital Humano y la Cultura Emprendedora en la Innovación. In XVII Congreso Nacional de ACEDE; Comunicación Oral: Sevilla, Spain, 2007.

93. Papa, A.; Santoro, G.; Tirabeni, L.; Monge, F. Social Media as Tool for Facilitating Knowledge Creation and Innovation in Small and Medium Enterprises. Balt. J. Manag. 2018, 13, 329-344. [CrossRef]

94. Díaz, N.L.; Aguiar, I.; De Saá, P. The Effect of Technological Knowledge Assets on Performance: The Innovative Choice in Spanish Firms. Res. Policy 2008, 37, 1515-1529. [CrossRef]

95. Olander, H.; Vanhala, M.; Hurmelinna-Laukkanen, P.; Blomqvist, K. Preserving Prerequisites for Innovation: Employee-related Knowledge Protection and Organizational Trust. Balt. J. Manag. 2016, 11, 493-515. [CrossRef]

96. Kianto, A.; Sáenz, J.; Aramburu, N. Knowledge-Based Human Resource Management Practices, Intelectual Capital and Innovation. J. Bus. Res. 2017, 81, 11-20. [CrossRef]

97. Xie, X.; Fang, L.; Zeng, S.; Huo, J. How does knowledge inertia affect firms' product innovation? J. Bus. Res. 2016, 69, 1615-1620. [CrossRef]

98. Bhatti, W.A.; Larimo, J.; Carrasco, I. Strategy's Effect on Knowledge Sharing in Host Country Networks. J. Bus. Res. 2016, 69, 4769-4774. [CrossRef]

99. Yam, R.C.M.; Cheng, J.; Fai, K.; Tang, E.P.Y. An Audit of Technological Innovation Capabilities in Chinese Firms: Some Empirical Findings in Beijing, China. Res. Policy 2004, 33, 1123-1140. [CrossRef]

100. Salman, N.; Saives, A. Indirect Networks: An Intangible Resource for Biotechnology Innovation. RED Manag. 2005, 35, 203-215. 
101. Aiman-Smith, L.; Goodrich, N.; Roberts, D.; Scinta, J. Assessing Your Organization's Potential for Value Innovation. Res. Technol. Manag. 2005, 48, 37-42. [CrossRef]

102. Subramaniam, M.; Youndt, M.A. The Influence of Intellectual Capital on the Types of Innovative Capabilities. Acad. Manag. J. 2005, 48, 450-463. [CrossRef]

103. Curado, C. Perceptions of knowledge management and intellectual capital in the banking industry. J. Knowl. Manag. 2008, 12, 141-165. [CrossRef]

104. Armstrong, J.S.; Overton, T.S. Estimating Nonresponse Bias in Mail Surveys. J. Mark. Res. 1977, 14, $396-402$. [CrossRef]

105. Youndt, M.A.; Snell, S.A. Human resource configurations, intellectual capital, and organizational performance. J. Manag. Issues 2004, 16, 337-360.

106. Lepak, D.P.; Takeuchi, R.; Snell, S.A. Employment flexibility and firm performance: Examining the interaction effects of employment mode, environmental dynamism, and technological intensity. J. Manag. 2003, 29, 681-703.

107. Snell, S.A.; Dean, J.W. Integrated Manufacturing and Human Resource Management: A Human Capital Perspective. Acad. Manag. J. 1992, 35, 467-504.

108. Hermans, R.; Kauranen, L. Value creation potencial of intelectual capital in biotechnology-empirical evidence from Finland. RED Manag. 2005, 35, 171-185.

109. Cheng, C.J.; Huang, J.W. Strategic Human Resource Practices and Innovation Performance-The Mediating Role of Knowledge Management Capacity. J. Bus. Res. 2009, 62, 104-114. [CrossRef]

110. Chen, J.; Zhu, Z.; Xie, H.Y. Measuring Intellectual Capital: A New Model and Empirical Study. J. Intellect. Cap. 2004, 5, 195-212. [CrossRef]

111. Huergo, E. The Role of Techonological Management as a Source of Innovation: Evidence from Spanish Manufacturing Firms. Res. Policy 2006, 35, 1377-1388. [CrossRef]

112. Goh, S.; Richards, G. Benchmarking the learning capacity of organizations. Eur. Manag. J. 1997, 15, $575-583$. [CrossRef]

113. Argyris, C. Knowledge for Action: A Guide to Overcoming Barriers to Organizational Change; Jossey-Bass: San Francisco, CA, USA, 1993.

114. Hult, G.T.; Ferrell, O.C. Global organizational learning capacity in purchasing: Construct and measurement. J. Bus. Res. 1997, 40, 97-111. [CrossRef]

115. De Saá-Pérez, P.; Díaz-Díaz, N.L. Human Resource Management and Innovation in the Canary Islands: An Ultra-peripheral Region of the European Union. Int. J. Hum. Resour. Manag. 2010, 21, 1649-1666. [CrossRef]

116. Camison-Zornoza, C.; Lapiedra-Alcami, R.; Segarra-Cipres, M.; Boronat-Navarro, M. A Meta-Analysis of Innovation and Organizational Size. Organ. Stud. 2004, 25, 331-361. [CrossRef]

117. Graves, S.B.; Langowitz, N.S. Innovative productivity and returns to scale in the pharmaceutical industry. Strateg. Manag. J. 1993, 14, 593-605. [CrossRef]

118. Rothwell, R.; Dodgson, M. Innovation and Size of Firm. In The Handbook of Industrial Innovation; Dodgson, M., Rothwell, R., Eds.; Edward Elgar Publishing: Cheltenham, UK, 1994; pp. 310-324.

119. Adams, W.J. Firm size and research activity: France and the United States. Q. J. Econ. 1970, 84, 386-409. [CrossRef]

120. Worley, J. Industrial research and the new competition. J. Political Econ. 1961, 69, 183-186. [CrossRef]

121. Rothwell, R. The Role of Small Firms in Technological Innovation. In The Survival of the Small Firm; Curran, J., Stanworth, J., Watkins, D., Eds.; Gower: London, UK, 1986; Volume 2, pp. 114-139.

122. Pavitt, K.; Robson, M.; Townsend, J. The size distribution of innovative firms in the UK: 1945-1983. J. Ind. Econ. 1987, 35, 297-316. [CrossRef]

123. Huergo, E.; Jaumeandreu, J. How Does Probability of Innovation Change with Firm Age? Small Bus. Econ. 2004, 22, 193-207. [CrossRef]

124. Busom, I. Los proyectos de I + D de las empresas: Un análisis empírico de algunas de sus características. Rev. Española De Econ. 1993, 10, 39-65.

125. Kumar, N.; Saqib, M. Firm size, opportunities for adaptation and in-house R\&D activity in developing countries: The case of Indian manufacturing. Res. Policy 1996, 25, 713-722.

126. Kuemmerle, W. Optimal scale for research and development in foreign environments: An investigation into size and performance of research and development laboratories abroad. Res. Policy 1998, 27, 111-126. [CrossRef] 
127. Gumbau, M. Análisis microeconómico de los determinantes de la innovación: Aplicación a las empresas industriales españolas. Rev. Española De Econ. 1997, 14, 41-66.

128. Molero, J.; Buesa, M. Patterns of technological change among Spanish innovative firms: The case of the Madrid region. Res. Policy 1996, 25, 647-663. [CrossRef]

129. Shipton, H.; Fay, D.; West, M.A.; Patterson, M.; Birdi, K. Managing People to Promote Innovation. Creat. Innov. Manag. 2005, 14, 118-128. [CrossRef]

130. Hair, J.F., Jr.; Anderson, R.E.; Tatham, R.L.; Black, W.C. Análisis Multivariante, 5th ed.; Pearson-Prentice Hall: Madrid, Spain, 2004.

131. Jöreskog, K.G.; Sörbom, D. LISREL8: Structural Equation Modeling with the SIMPLIS Command Language; Scientific Software International: Chicago, IL, USA, 1993.

132. Browne, M.W.; Cudeck, R. Alternative Ways of Assessing Model Fit. In Testing Structural Equation Models; Bollen, K.A., Long, J.S., Eds.; Sage: Beverly Hills, CA, USA, 1993; pp. 136-162.

133. Stanovicic, T.; Pekovic, S.; Bouziri, A. The Effect of Knowledge Management on Environmental Innovation: The Empirical Evidence from France. Balt. J. Manag. 2015, 10, 413-431. [CrossRef]

134. Ortega-Egea, M.T.; Ruiz-Moreno, A.; Haro-Dominguez, C. Determinants of Innovative Behavior of Employees: Evidence from Spanish Firms. Empl. Relat. 2014, 3, 606-621. [CrossRef]

135. Viitala, R.; Kantola, J. Temporary Agency Workers Shake a Word Community: A Social Capital Perspective. Empl. Relat. 2016, 3, 147-162. [CrossRef]

136. Onag, A.O.; Tepeci, M.; Basalp, A.A. Organizational Learning Capability and its Impact on Firm Innovativeness. Procedia Soc. Behav. Sci. 2014, 15, 708-717. [CrossRef]

137. Tapio-Inkinen, H.; Kianto, A.; Vanhala, M. Knowledge Management Practices and Innovation Performance in Finland. Balt. J. Manag. 2015, 10, 432-455. [CrossRef]

138. Buckley, P.J.; Carter, M.J. Process and structure in knowledge management practices of British and US multinational enterprises. J. Int. Manag. 2002, 8, 29-48. [CrossRef]

(C) 2020 by the authors. Licensee MDPI, Basel, Switzerland. This article is an open access article distributed under the terms and conditions of the Creative Commons Attribution (CC BY) license (http://creativecommons.org/licenses/by/4.0/). 